\title{
The Determinants of Neighborhood Based Development Policy Implementation in Manado City
}

\author{
Jeane Elisabeth Langkai, Haedar Akib, Recky H E Sendouw
}

\begin{abstract}
The purpose of this study was to analyze the determination of neighborhood-based development policies in the city of Manado by using a phenomenological qualitative agreement. Data collection techniques are: observation in several Neighborhood, semi-structured in-depth interviews and documents obtained from the Community Empowerment Agency and the Village Government. Data analysts performed through technical analysis of Miles and Huberman. The results of the study show that the determinant of the implementation of the Neighborhood-Based Development policy in Manado City are: 1). Disposition or commitment of the Manado City government that sets policy as a top priority and tends to be weak, 2). The standards and objectives of the policy are too ideal (utopian), very difficult for the implementers to realize, 3). Erroneously setting the allocation of resources on capital expenditure, should be included in goods and services expenditure and implementation of the policy awaiting changes in the regional income and expenditure budget changes in November, 4). Changes in the Central Government's policy, namely Minister of Home Affairs Regulation No. 32/2011, which has not been anticipated, 5). Communication and socialization have not been carried out systematically, directed 6). The social conditions of the community have not been prepared to support policy implementation. For that reason: 1). The Manado City Government should have a genuine disposition or commitment in implementing a Neighborhood Based Development policy that has been set as a top priority and superior, 2). Policy standards and targets should be measurable and can be implemented, 3). Research in determining the allocation of resources for implementation, 4). Anticipating changes in Central Government policies, 5). Communication and socialization are carried out systematically, directed by broadcasting through print and mass media, 6). The social conditions of the community are carefully prepared, through community meetings, confessions, making brochures, stickers, and policy songs on neighborhood-based development.
\end{abstract}

Keywords: Neighborhood Based Development; Policy Implementation; Manado City; Indonesia.

\section{INTRODUCTION}

In order to accelerate the improvement of community

Revised Manuscript Received on September 22, 2019

Jeane Elisabeth Langkai, State Administration Study Program, Faculty of Social Sciences, Universitas Negeri Manado Indonesia 5618

Haedar Akib, State Administration Study Program, Faculty of Social Sciences Universitas Negeri Makassar Indonesia 90222

Recky H E Sendouw, State Administration Study Program, Faculty of Social Sciences, Universitas Negeri Manado Indonesia 5618. reckyhes@yahoo.com welfare, the city government of Manado implemented the Neighborhood-Based Development policy as a priority and superior policy. This policy aims specifically at building, improving: a) adequate infrastructure, b) income of weak economic communities through additional business capital, c) creative economy through infrastructure, social and economic activities programs in 504 neighborhoods in the city of Manado. This policy is a policy that is very ideal and difficult to implement the policy implementers are the Community Empowerment Agency and the Government and 504 Heads of the Neighborhood in the City of Manado, Policy implementers are faced with resource problems: a). not able to verify the proposal from 504 neighborhoods according to the time specified b). Head of Neighborhood who has not been able to formulate neighborhood problems, c) late recruitment of Village Facilitators, d) late payment of stimulant funds, e) weak coordination and socialization. On the other hand, the implementer is faced with the difficulty of the technical implementation of socialization, b) the unavailability of target databases, c) inconsistency in objectives, standards and objectives, d) resources. Based on these problems, an analysis of the determinants of the implementation of Neighborhood Based Development policies in the City of Manado was carried out.

\section{METHODOLOGY}

The purpose of this study is to analyze the determinants (determinants and inhibitors of success) in implementing the Neighborhood Based Development policy in the City of Manado. The approach taken is phenomenological qualitative. Neighborhood-based development policy is a policy with the aim of improving the welfare of the community, while the intended neighborhood is the lowest organizational structure in government organizations in the city of Manado. Data collection techniques are observation in several neighborhoods, semi-structured in-depth interviews to community leaders, implementers and documents obtained from the Community Empowerment Agency and the Village Government. The technical data analysis refers to the models of Miles and Huberman ${ }^{(1)}$. 


\section{RESULT AND DISCUSSION}

Some views that discuss policy determinants include: ${ }^{(2)}$. Mazmanian and Sabatier write that understanding policy implementation means trying to understand what changes occur after the program is formulated and implemented, ${ }^{(3)}$. Van Meter and Van Horn wrote that the determinants of policy implementation are influenced by: standards and policy objectives, resources, dispositions and commitments, (4). Edwards III formulates policy determinants in four aspects, namely: communication, resources, bureaucratic or implementing attitudes and organizational structure or bureaucratic work flow, (4) Grindle categorizes in two aspects, namely the contents of the policy and the implementation neighborhood ${ }^{(5)}$, and Nugroho, placing inadequate socialization as a determinant of policy, ${ }^{(6)}$.

The determinants of the implementation of the Neighborhood-Based Development policy in the City of Manado are as follows:

\section{A. Disposition of Government}

The Manado City Government established the Community Empowerment Agency and the Kelurahan (village) Government as technical implementers and Head of the Neighborhood as field implementers. In analyzing the determinants of policy implementation there are a number of views that discuss them including Van Meter and Van Horn who describe disposition aspects as characteristics and tendencies of implementer's behavior in implementing policies,(4a) while Mazmanian and Sabatier formulate a policy framework in three factors, namely independent, dependent and intervening. The disposition aspect is grouped on independent factors which are formulated as a form of support and commitment of implementing officials in implementing policies, (3a) Elmore classified the disposition aspect as the government's responsibility for implementing the policy, ${ }^{(7)}$ while Edward analyzes the disposition aspects of implementer's behavior, (5a). Government support is seen in their seriousness in placing the implementation of neighborhood-based development policies as a superior program through Mayor Regulation No. 46 of 2011. But in reality there are data that show the low commitment of the Manado City government including: a) the government mistakenly set its resources and has not attempted to change it in the following year, b) removing economic programs as a target of improving the welfare of the poor, c) social programs combined with infrastructure programs directed at the procurement of solar cell lights that are not in accordance with community needs in 504 neighborhoods, d). Not yet trying to anticipate changes in central government policies. The data shows that the determinant of policy implementation is the disposition or commitment of the Manado City government that has not seriously implemented the policy.

\section{B. Policy Standards and Objective}

Standards and policy targets that are too ideal (utopian) are very difficult for implementers to realize. Van Meter and Van Horn explain the measurement of the success of policy implementation explaining that measuring the performance of policy implementation means evaluating the level of achievement of standards and targets that must be fully understood because it is closely related to the disposition of implementers and this is crucial ${ }^{(8)}$. Policy standards and objectives are: a) increased participation of the entire community, in the decision-making process for development management, b) increased rooted, representative and accountable community institutional capacity, c) increased government capacity to provide services to the community directly (especially the poor), through policies, programs and pro-poor budgeting, d) increasing community synergy, local government, the private sector, associations, universities, non-governmental organizations, community organizations and other caring groups, to streamline efforts to empower and independence the community, e) increase social capital community that develops according to social and cultural potential based on local potential and $f$ ) increased innovation and utilization of appropriate technology, information and communication in community empowerment. While the target is: a) the construction of adequate infrastructure in every ward neighborhood with a face that is increasingly beautiful, clean and beautiful, b) increasing income of the weak economic community with the help of additional capital for small and micro enterprises, c) increasing community welfare d) encourage the community to synergize with various programs to improve community welfare in accordance with their aspirations and needs, e) produce superior products of creative economy, e) the availability of neighborhood programs as a result of community studies as a forum for communities to learn to plan, implement, supervise and care for their activities, (1a). Looking at these objectives, it can be said that this policy: a). Unrealistic, b). Too ideal and c). not yet adjusted to the conditions of the implementer's ability, d). have not considered the number of poor people and d). pluralist social conditions of society from religious, social, cultural, educational level and factors that cause poverty. The data shows that policy standards and targets are too ideal and difficult to achieve.

\section{Accurate Allocation of Resources}

Mazmanian, Hogword, Grindle, Edward III and Van Horn found that the allocation of resources is a determinant of policy implementation. This policy states that the source of funding for policy implementation is borne by the regional Revenue and Expenditure Budget. Minister of Home Affairs Regulation Number 32 Year 2011 stipulates that: grants in the form of money budgeted in indirect expenditure groups and formulated into programs and activities are described in the types of goods and services expenditure. The Regional Government Budget Team is tasked with preparing and implementing regional head policies in the framework of preparing the APBD in the form of Work Plans and

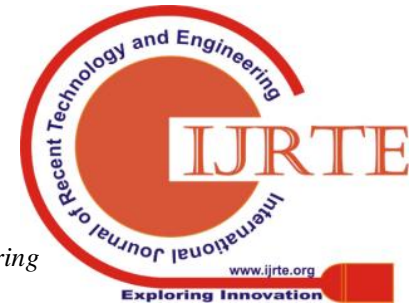


Budgets in planning and budgeting documents that contain programs, activities and budgets as documents for the implementation of budgetary financial institutions as Regional General Treasurers, (8)(9). The distribution of policy funds is done in stages where the first stage is given 40 percent and the second stage is 30 percent and the third stage is given 30 percent. When the implementation of government policies mistakenly includes the source of funds in capital expenditure, the expenditure on goods and services as a result of the implementation of the policy must wait for the budget changes set in November while accountability in December. This condition is increasingly difficult with the changes in the central government's policy which stipulates that social assistance in the form of money is budgeted in indirect expenditure groups, types of social assistance expenditure, objects of social assistance spending, and details of objects of social assistance spending in Regional Financial Management Officials. Based on these data it can be said that the accuracy of the allocation of resources is a determinant of the implementation of policies.

\section{Changes in Central Government Policy}

Minister of Home Affairs Regulation Number 32 Year 2011 stipulates that: grants in the form of money budgeted in indirect expenditure groups and formulated into programs and activities are described in the types of goods and services expenditure. Subsequently grants as giving money or goods to individuals, families, or groups are being given social assistance in the form of money or goods that are not continuously and selectively to protect against the possibility of social risks with the aim of restoring and developing the ability of someone with a dysfunction social in order to meet minimum basic needs. Grants in the form of budgeted funds in the expenditure group are not directly formulated into goods and services shopping programs, objects of shopping for goods and services grants by including the names of recipients and the amount of grants, and details of objects of shopping for goods or services. When the policy is implemented, the realization of grants in the form of goods and services is converted according to government accounting standards in the budget realization report and disclosed in the notes to financial statements in the preparation of regional government financial reports. Social assistance in the form of money to individuals and / or families consists of social assistance to individuals and / or families planned and which cannot be planned in advance. Ceiling of budget allocations that cannot be planned in advance does not exceed the planned budget allocation ceiling. Changing central government policies have an impact on the collision of social programs that cannot be realized according to standards and targets. This change in central policy is a determinant in the implementation of social programs.

\section{E. Communication and Socialization}

Van Mater and Van Horn, Edward III explained the role and function of communication between implementers and socialization to related parties is a determinant of policy implementation. For this reason, communication and socialization must be carried out in a planned, integrated and intact manner so that there are similar perceptions about policy goals and objectives. Data shows that technical implementers: a). Not understand correctly about policy, b). Not able to formulate neighborhood problems and c). Not able to make an activity proposal. This condition is in line with Nugroho's view, which writes that adequate socialization provides an adequate contribution to implementation.

\section{F. Social Conditions of the Communities to Support Policy Implementation}

This neighborhood - based development policy aims to empower the poor, to increase their dignity and dignity to escape poverty. ${ }^{(8)}$ explains the approach to policy implementation namely approach top down is similar to the command and control approach and the bottom up approach is similar to the market approach. The top down or command and control approach is carried out centrally while the bottom up approach highlights the implementation of policies formulated from community initiatives, ${ }^{(10)}$. The social condition of the people in the community is not yet ready to support the implementation of the policy. The Manado City government has agreed to implement the implementation of supporting policies through reconciliation efforts. Because this is a city chosen by the Manado City government, which was not chosen by the community. For this reason, efforts are needed to create an atmosphere that supports the implementation of policies that are realized as stated goals. 
Table 1. Summary of Research Findings Determination of Implementation of Neighborhood-Based Development Policies in Manado City

\begin{tabular}{|c|c|c|c|}
\hline $\begin{array}{l}\text { Researc } \\
\text { h focus }\end{array}$ & $\begin{array}{c}\text { Ideal } \\
\text { condition }\end{array}$ & Research result & Synthesis \\
\hline $\begin{array}{c}\text { Determin } \\
\text { ants } \\
\text { (inhibitin } \\
\text { g factors } \\
\text { and } \\
\text { determin } \\
\text { ants) of } \\
\text { the } \\
\text { impleme } \\
\text { ntation of } \\
\text { the } \\
\text { Neighbor } \\
\text { hood } \\
\text { Based } \\
\text { Develop } \\
\text { ment } \\
\text { policy in } \\
\text { the City } \\
\text { of } \\
\text { Manado }\end{array}$ & $\begin{array}{l}\text { Determine } \\
\text { the } \\
\text { implemen } \\
\text { tation of } \\
\text { Mazmani } \\
\text { an and } \\
\text { Sabatier } \\
\text { policies, } \\
\text { Van } \\
\text { Meter and } \\
\text { Van Horn, } \\
\text { Edward } \\
\text { III. } \\
\text { Grindle, } \\
\text { Nugroho } \\
\text { Riant. } \\
\text { Elmor, } \\
\text { Agustino, } \\
\text { Leo. }\end{array}$ & 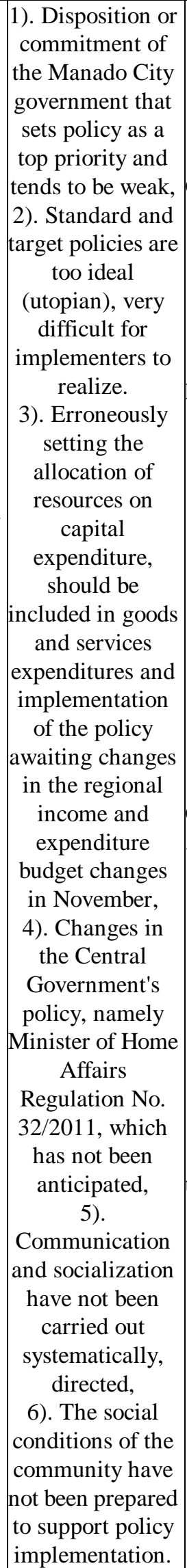 & $\begin{array}{l}\text { The Manado City } \\
\text { Government should } \\
\text { have a genuine } \\
\text { disposition or } \\
\text { commitment in } \\
\text { implementing a } \\
\text { Neighborhood-Bas } \\
\text { ed Development } \\
\text { policy that has been } \\
\text { set as a top priority } \\
\text { and priority, 2). } \\
\text { Policy standards } \\
\text { and targets should } \\
\text { be measurable and } \\
\text { can be } \\
\text { implemented, 3). } \\
\text { Research in } \\
\text { determining the } \\
\text { allocation of } \\
\text { implementation } \\
\text { resources, 4). } \\
\text { Anticipating } \\
\text { changes in Central } \\
\text { Government policy, } \\
\text { 5). Communication } \\
\text { and socialization } \\
\text { are carried out } \\
\text { systematically, } \\
\text { directed by } \\
\text { broadcasting } \\
\text { through print and } \\
\text { mass media, 6). } \\
\text { The social } \\
\text { neighborhood-base } \\
\text { d development. } \\
\text { conditions of the } \\
\text { community are } \\
\text { carefully prepared, } \\
\text { through community } \\
\text { meetings, } \\
\text { confessions, } \\
\text { making brochures, } \\
\text { stickers, and policy }\end{array}$ \\
\hline
\end{tabular}

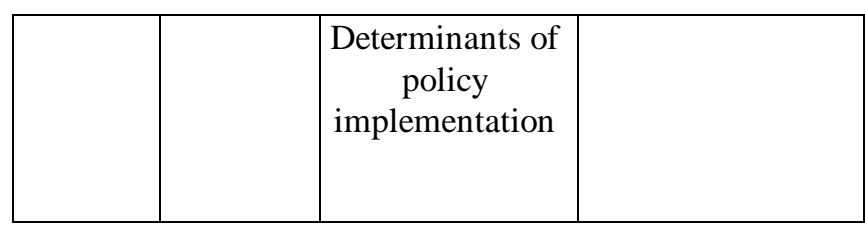

\section{CONCLUSION}

This study concluded that the determinants of the implementation of the Neighborhood-Based Development policy in Manado City are:

- Disposition or commitment of the Manado City government that sets policy as a top priority and tends to be weak

- The standards and objectives of the policy are too ideal (utopian), very difficult for the implementers to realize

- It is wrong to determine the allocation of resources on capital expenditure, should be included in the expenditure of goods and services

- Changes in the Central Government's policy, namely Minister of Home Affairs Regulation No. 32/2011, which has not been anticipated,

- Communication and socialization have not been carried out systematically, directed and intact.

- The social conditions of the community have not been prepared to support policy implementation.

\section{REFERENCES}

[1] Miles, Matthew B. AMH. Analisis Data Kualitatif. Terjemahan Tjetjep Rohendi Rohidi. Jakarta: Universitas Indonesia; 1992.

[2] Buku Pedoman Umum Pembangunan Berbasis Lingkungan. Manado: Pemerintah Kota Manado; 2012.

[3] Mazmanian Daniel and Paul A. Sabatier. Effective Policy Implementation. Lexington Mass DX; 1981. 220 p.

[4] Edward III GC. Implementing Public Policy. Washington D.C.: Congressional Quarterly Press; 1980.

[5] Grindle MS. Politics and policy implementation in the Third World. Vol.4880. New Jersey: Princeton University Press; 2017

[6] Nugroho R. Public Policy: Dinamika Kebijakan, Analisis Kebijakan, dan Manajemen Politik Kebijakan Publik. Jakarta: Elex Media Komputindo. 2017.

[7] Elmore RF. Forward and Backword Mapping: Reversible Logic in the Analysis of Public Policy. In: Policy implementation in federal and unitary systems. Springer; 1985. p. 33-70.

[8] Agustino L. Dasar-dasar kebijakan publik (Edisi Revisi). Alf Bandung. 2016

[9] Atas P, Menteri P, Negeri D, Tahun N, Dalam M, Republik N. Salinan Menteri Dalam Negeri Republik Indonesia. 2012;1-7.

[10] Stewart, Jr., J., Hedge, D. M., \& Lester JP. Public Policy: An Evolutionary Approach. Public Policy: An Evolutionary Approach. 2008

\section{AUTHORS PROFILE}

I am Jeane Elisabeth Langkai, I am associated with State Administration Study Program, Faculty of Social Sciences, Universitas Negeri Manado Indonesia 5618. My interest is social science.

My name is Haedar Akib, I am attached with State Administration Study Program, Faculty of Social Sciences Universitas Negeri Makassar Indonesia 90222. Myarea of interest is social science

My name is Recky $\mathbf{H}$ E Sendouw, I am associated with State Administration Study Program, Faculty of Social Sciences, Universitas Negeri Manado Indonesia 5618. .my area of interest is social science. 